\title{
MEIS1 wt Allele
}

National Cancer Institute

\section{Source}

National Cancer Institute. MEIS1 wt Allele. NCI Thesaurus. Code C51284.

Human MEIS1 wild-type allele is located within 2p14-p13 and is approximately 137 kb in length. This allele, which encodes homeobox protein Meis1, is involved in crucial aspects of development. 